\title{
Investigation of Relationship between Coach and Athlete in terms of Different Variables
}

\author{
Fikret Ramazanoğlu
}

Faculty of Sports Sciences, Sakarya University, Sakarya, Turkey

Copyright $\mathrm{O} 2018$ by authors, all rights reserved. Authors agree that this article remains permanently open access under the terms of the Creative Commons Attribution License 4.0 International License

\begin{abstract}
This research was conducted for the purpose of establishing the relationship of individuals doing sports in various branches in the Province Ağrı with their coaches in terms of the branch they are engaged in and some demographical variables. In the research, a method oriented to the descriptive survey which aims to present the present situation was used. The research group is consisted of totally 95 athletes; 28 of whom are females and 67 are males who do sports in various branches in Ağr1. The Scale of Coach-Athlete Relationship (S-CAR) which was developed by Jowett and Ntoumanis (2004), measures the quality of coach-athlete relationship and was adapted into Turkish by Ekenci et al., (2017) was used as data collection tool. Mann-Whitney U Test was used for the paired comparison and Kruskal-Wallis Variance Analysis was used for multiple comparisons in the analysis of data. In cases where there is significant difference at the end of Kruskal Wallis Variance Analysis in the multiple comparisons, Mann Whitney U Test was applied for determining that which groups caused to this difference. $\mathrm{p}=0.05$ was selected for the significance level in the research. At the end of the research, it was found out that the age variable does not vary significantly in the coach-athlete relationship. Again there are no significant differences by the license years and branch variable. However, it was found that there are significant variables when gender and educational background of the participants were examined.
\end{abstract}

Keywords Coach, Athlete, Physical Education and Sports, Coach Athlete Relationship

\section{Introduction}

A ruling and ruled persons have been always present in the lives since the individuals have started to live as a society. This always started in every section ranging from the family which is the smallest unit and continued to the nation which is a large society. It is seen that there are cases such as differences of opinions, cooperation difficulties of individuals and division of labor and specialization aiming differentiation between those who are ruled and do rule and in the path going to that aim. Such these cases caused the concepts such as administrators and coaches to emerge in the society [1].

Every person acquire some positive or negative impressions starting from certain characteristics from appearances to the behaviors about the persons with whom they are in communication, and develop some expectations starting from here. This situation is a process developed beyond the control of the person to some extent and usually without realizing it [2].

In Robbins et al., communication is defined as "the transfer of meaning and understanding to the person [3]. It is desirable to master communication, to jump to the level of unconscious qualification. The relationship between thought, feeling and behavior needs to be understood sufficiently. How the universe is a cybernetic whole is a part of the individual as a part of it. This means that there is a mutual and continuous interaction between body, thought and emotion. There is a law of this dialect [4]. Clear, direct and honest communication is of utmost importance. Because individuals who are able to communicate effectively and in a healthy way, they are more satisfied and satisfied and feel happier [5].

Coach is the person who helps athletes to develop physical, physiological, cognitive, psychological and social capacities with purposive behaviors, fulfills the scientific objectives for this and receives a specific education-training. In a study conducted on the licensed athletes, "training" and "coach" are on the first rank among the factors which can affect the sportive success positively [6]. The coach is the person who brought the personality characteristics required for the athlete to be successful and factors such as motivation in the athlete. No matter how talented an athlete is and no matter how hard he/she works, an athlete needs the knowledge and experience of the coach to be successful. The coach is the person who serves as a bridge between the athletes and scientists who make sports research. He/she interprets the latest 
information developed in the sports field, compares it with his/her own trials and then transfers to the athlete in the most properly way [7].

The one who is the architect of the performance and success in the sports clubs, plans the prospective strategies in the team and uses unique methods for achieving these objectives is not another person than the coach. The coach is the person who is always together with the athletes, recognizes them and meets their requirements [1]. From this point of view, the positive coach-athlete relationship in the environment where positive communication processes are experienced and positive relations are established provides a suitable environment for improving the athlete motivation and athlete satisfaction as well as improving the skills of the athletes [8].

Today, the relationship between the coach and athlete is of importance in terms of reaching success. The coaches should take the family structure where the athlete is grown up, his/her values, beliefs and personal characteristics into account and should give an opportunity to the athletes having problem to identify the problems. The coach and athlete should respect each other mutually, accept each other's existence, make each other to feel that they are precious and accept each other as is. Feeling being accepted is to feel being loved, trusted and respected. Accepting a person together with what he/she says, thinks and feels as a person is to respect his/her individualism, difference and uniqueness. A coach having a good communication with his/her athlete has the chance of being more successful in influencing, training his/her athlete and working together [9].

As a result, many coaches today have enough psychological training they do not benefit. Many coaches and team managers see the athletes as persons who perform physical, technical and tactical tasks. Psychological preparations are tried to be done verbally. However, psychological training considering the positive effect on performance, both coaches it is necessary to make the athletes more conscious [10].

In this context, it is aimed to investigate the relationship between coaches and the coaches of the sportsmen in various clubs in and around Ağrı province. Different variables were examined in the study and the relations between the coaches of the athletes were tried to be revealed by these variables and the study was concluded.

\section{Method}

\section{Research Model}

In the research, a method for descriptive survey and relational survey intended to find out the present state, was used. The descriptive survey models are the research approach which aims to describe a past or still existing situation as is. The case, individual or object that is the subject of the research is tried to be described within its own conditions and as is. No effort for changing and affecting them in any way is made. The relational survey models are the research models intended to determine covariance existence and/or degree among two or more variables [11].

\section{Population and Sampling}

The population of the research is consisted of athletes who do sports in various clubs of the province Ağrı and its counties. It was not applied to the sampling in order to obtain reliable data, it was studies on the whole population and "the population sampling itself" [12] was accepted as the population of research's study population. In the research, it was tried to apply questionnaire onto the whole population, however, the study was limited with 95 athletes totally, 28 of whom were females and 67 males, due to the athletes who did not want to participate into the questionnaire voluntarily and were not present in the club at the moment when the study was conducted, and they constituted the sampling group of the research.

\section{Data Collection Tools}

The data collection tool produced in the study is divided into two parts. Data collection tool demographic calculations of needs for first-class research protocol statements. In the second part; In 2004, Jowett and Ntoumanis Developed by the UK, [13] and was adapted into Turkish by Ekenci et al., (2017) was used as data collection tool [14], coach athletes test the reliability of the scale (The Coach-Athlete Relationship Questionnaire CART-Q) consists of 23 items, "Absolutely I do not participate" and "I totally agree". The questionnaire was designed to measure the relationship between coach and athlete, closeness, reciprocal co-orientation, complementarity, and so on. It consists. The Cronbach alpha reliability coefficient for the scale were calculated by researchers $\alpha=.80, \alpha=.78, \alpha=.85$, respectively [13]. Article 16 of the original scale, the statement of "appropriate work" in Article 15 is a conditional expression that can be measured while talking Obvious. In order to avoid the multiple connections, item 16 is excluded from the scale in the preliminary work result.

\section{Data Analysis}

In the analysis phase of the data, whether the sub-dimensions of the coach-athlete relationship scale show normal distribution or not was tested with Kolmogorov-Smirnov test and Shapiro-Wilk test for establishing that whether the difference between group means for demographical variables is significant or not. The results in all variables in these analyses were significant. That is, it was found that all variables do not 
show normal distribution. For this reason, the independent variables for the sub-problems; coach-athlete relationship perceptions of the participants were tested with non-parametrical tests. Mann-Whitney U Test was used for the paired comparison and Kruskal-Wallis Variance Analysis was used for multiple comparisons in the analysis of data. In cases where there is significant difference at the end of Kruskal Wallis Variance Analysis in the multiple comparisons, Mann Whitney U Test was applied for determining that which groups caused to this difference. Data obtained were analyzed in SPSS (Statistical Package for Social Scientists for Windows Release 23.0) program in the computer; the significance was tested at 0.05 level.

\section{Findings}

When Table 1 was examined, it was found out that there were no significant differences in the complementing each other $(\mathrm{U}=808,000 ; \mathrm{P}>0.05)$ and intimacy $(\mathrm{U}=873,000 ; \quad \mathrm{P}>0.05)$ dimensions of the sub-dimensions of the coach-athlete relationship scale of the research's participants and gender variable. When the mutual communication dimension $(\mathrm{U}=699,500 ; \mathrm{P}<0.05)$ was examined, it was seen that it significantly varied by the gender. It was seen that female athletes' rank means are higher than those of male athletes. We can say that it demonstrated that females are better in the mutual communication with their coaches than the males.

In Table 2, sub-dimensions of the coach-athlete relationship scale and age, of the demographical variables, were examined and the following results were obtained: it was found that there were no significant differences between complementing each other $\left[\mathrm{X}_{(2)}^{2}=, 566 ; \mathrm{P}>0.05\right]$ mutual communication $\left[\mathrm{X}^{2}{ }_{(2)}=, 304 ; \mathrm{P}>0.05\right]$ and intimacy $\left[\mathrm{X}_{(2)}^{2}=, 332 ; \mathrm{P}>0.05\right]$, of the sub-dimensions of the coach-athlete relationship, and the age variable. That is, it is possible to say that the age is not a determinant in the coach-athlete relationship.

Table 1. Results of Mann Whitney U Test Showing the Comparison of Sub-dimensions of Scale of the Coach-Athlete Relationship of the Research's Participants by the Gender

\begin{tabular}{cccccc}
\hline $\begin{array}{c}\text { Scale of Coach-Athlete } \\
\text { Relationship }\end{array}$ & Gender & N & Rank Mean & Rank Total & P \\
\hline \multirow{2}{*}{ Complementing Each Other } & Male & 67 & 43,36 & 1214,00 & 808,000 \\
& Female & 28 & 49,94 & 3346,00 & 1105,50 \\
Mutual communication & Male & 67 & 39,48 & 3454,50 & 699,500 \\
& Female & 28 & 51,56 & 1279,00 & $848 *$ \\
Intimacy & Male & 67 & 45,68 & 3281,00 &, 590 \\
\hline
\end{tabular}

$\mathrm{P}=0,05$

Table 2. The Results of Kruskal Wallis Test Showing the Comparison of Sub-dimensions of Scale of the Coach-Athlete Relationship of the Research's Participants by the Age Groups

\begin{tabular}{|c|c|c|c|c|c|c|}
\hline Scale of Coach-Athlete Relationship & Age & $\mathbf{N}$ & Rank Mean & df & $\mathbf{X}^{2}$ & $\mathbf{P}$ \\
\hline \multirow{3}{*}{ Complementing each other } & 16 years old and below & 38 & 49,38 & \multirow{3}{*}{2} & \multirow{3}{*}{, 566} & \multirow{3}{*}{,754 } \\
\hline & $\begin{array}{c}\text { Between } 17 \text { and } 19 \\
\text { years old }\end{array}$ & 37 & 48,78 & & & \\
\hline & 20 years old and above & 20 & 43,93 & & & \\
\hline \multirow{3}{*}{ Mutual communication } & 16 years old and below & 38 & 49,58 & \multirow{3}{*}{2} & \multirow{3}{*}{,304 } & \multirow{3}{*}{,859 } \\
\hline & $\begin{array}{c}\text { Between } 17 \text { and } 19 \\
\text { years old }\end{array}$ & 37 & 47,77 & & & \\
\hline & 20 years old and above & 20 & 45,43 & & & \\
\hline \multirow{3}{*}{ Intimacy } & 16 years old and below & 38 & 49,34 & \multirow{3}{*}{2} & \multirow{3}{*}{, 332} & \multirow{3}{*}{, 847} \\
\hline & $\begin{array}{c}\text { Between } 17 \text { and } 19 \\
\text { years old }\end{array}$ & 37 & 48,22 & & & \\
\hline & 20 years old and above & 20 & 45,05 & & & \\
\hline
\end{tabular}

$\mathrm{P}=0,05$ 
Table 3. The Results of Kruskal Wallis Test Showing the Comparison of the Sub-dimensions of Scale of the Coach-Athlete Relationship of the Research's Participants by the Branch Groups

\begin{tabular}{|c|c|c|c|c|c|c|}
\hline Scale of Coach-Athlete Relationship & Branch & $\mathbf{N}$ & Rank means & df & $X^{2}$ & $\mathbf{P}$ \\
\hline \multirow{6}{*}{ Complementing each other } & Athletics & 28 & 60,21 & \multirow{6}{*}{5} & \multirow{6}{*}{9,580} & \multirow{6}{*}{, 880} \\
\hline & Boxing & 10 & 49,60 & & & \\
\hline & Wrestling & 14 & 41,82 & & & \\
\hline & Weight Lifting & 12 & 37,17 & & & \\
\hline & Skiing & 16 & 47,09 & & & \\
\hline & Tennis & 15 & 39,53 & & & \\
\hline \multirow{6}{*}{ Mutual communication } & Athletics & 28 & 49,89 & \multirow{6}{*}{5} & \multirow{6}{*}{3,451} & \multirow{6}{*}{,631 } \\
\hline & Boxing & 10 & 52,50 & & & \\
\hline & Wrestling & 14 & 55,61 & & & \\
\hline & Weight Lifting & 12 & 45,42 & & & \\
\hline & Skiing & 16 & 46,06 & & & \\
\hline & Tennis & 15 & 38,50 & & & \\
\hline \multirow{6}{*}{ Intimacy } & Athletics & 28 & 41,96 & \multirow{6}{*}{5} & \multirow{6}{*}{9,359} & \multirow{6}{*}{,096 } \\
\hline & Boxing & 10 & 44,35 & & & \\
\hline & Wrestling & 14 & 51,00 & & & \\
\hline & Weight Lifting & 12 & 67,96 & & & \\
\hline & Skiing & 16 & 41,13 & & & \\
\hline & Tennis & 15 & 50,27 & & & \\
\hline
\end{tabular}

$\mathrm{P}=0,05$

Table 4. The Results of Kruskal Wallis Test Showing the Comparison of the Sub-dimensions of Scale of the Coach-Athlete Relationship of the Research's Participants by the School They Studied

\begin{tabular}{|c|c|c|c|c|c|c|c|c|}
\hline $\begin{array}{c}\text { Scale of Coach-Athlete } \\
\text { Relationship } \\
\end{array}$ & & $\begin{array}{c}\text { Educational } \\
\text { Status }\end{array}$ & $\mathbf{N}$ & $\begin{array}{c}\text { Rank } \\
\text { means }\end{array}$ & df & $\mathbf{X}^{2}$ & $\mathbf{P}$ & $\begin{array}{l}\text { Significant } \\
\text { difference }\end{array}$ \\
\hline Complementing each other & $\begin{array}{l}\text { A } \\
\text { B } \\
\text { C }\end{array}$ & $\begin{array}{l}\text { Secondary } \\
\text { High school } \\
\text { University }\end{array}$ & $\begin{array}{l}69 \\
16 \\
10\end{array}$ & $\begin{array}{l}48,51 \\
45,59 \\
48,30\end{array}$ & 2 & , 148 & ,929 & - \\
\hline Mutual communication & $\begin{array}{l}\text { A } \\
\text { B } \\
\text { C }\end{array}$ & $\begin{array}{l}\text { Secondary } \\
\text { High school } \\
\text { University }\end{array}$ & $\begin{array}{l}69 \\
16 \\
10\end{array}$ & $\begin{array}{l}50,17 \\
36,66 \\
51,20\end{array}$ & 2 & 3,290 & ,193 & - \\
\hline Intimacy & $\begin{array}{l}\text { A } \\
\text { B } \\
\text { C }\end{array}$ & $\begin{array}{l}\text { Secondary } \\
\text { High school } \\
\text { University }\end{array}$ & $\begin{array}{l}69 \\
16 \\
10\end{array}$ & $\begin{array}{l}52,43 \\
34,09 \\
39,70\end{array}$ & 2 & 6,973 & ,031* & $\mathrm{B}<\mathrm{A}$ \\
\hline
\end{tabular}

$\mathrm{P}=0,05$

In Table 3, when the sub-dimensions of the scale of coach-athlete relationship of the research participants were examined, it was found out that there were no significant differences between complementing each other $\left[\mathrm{X}_{(5)}=9,580 ; \mathrm{P}>0.05\right]$, mutual communication $\left[\mathrm{X}^{2}{ }_{(5)}=\right.$ $3,451 ; \mathrm{P}>0.05]$ and intimacy $\left[\mathrm{X}^{2}{ }_{(5)}=9,359 ; \mathrm{P}>0.05\right]$, of the sub-dimensions, and the sports branch at the significant levels. It is possible to say that which sports branch the participants are engaged in did not lead to any change in their relationships with the coach, the branch is not effective in the communication.

In Table 4, when the sub-dimensions of the scale of coach-athlete relationship of the research participants were examined, it was found out that there were no significant differences between complementing each other $\left[\mathrm{X}_{(2)}^{2}=, 148 ; \mathrm{P}>0.05\right]$, mutual communication $\left[\mathrm{X}_{(2)}^{2}=\right.$ $3,290 ; \mathrm{P}>0.05]$, of the sub-dimensions, and the school they studies at the significant levels. However, it was found that there were significant differences in intimacy sub-dimension $\left[\mathrm{X}_{(2)}^{2}=6,973 ; \mathrm{P}<0.05\right]$.

Mann Whitney U-test was performed for determining that the difference observed between the groups was originated from which groups. According to the test results; the rank means of the athletes who study in secondary school became evident compared with others. That is, it was seen that the intimacy dimension of athletes who study 
at secondary school significantly varied than the athletes who study at high school, they establish relationships with their coaches in more intimacy compared with others.

\section{Discussion and Conclusion}

In the research, it was aimed to determine the relationships of athletes who compete in different clubs located in the Province Ağrı with their coaches in terms of different variables and the following results were obtained:

When the research findings were examined, it was determined that female participants use the mutual communication dimension, of the sub-dimension of the coach-athlete relationship scale, in a more evident way than the male participants, in the gender variable (table 1).

When the literature of the related field was examined, it is seen that there are studies having similar research results. Of these, Yücel (2010) found out in his study related with wrestlers that there were significant differences in favor of female participants in coordination and intimacy and sense of trust factors in the coach-athlete relationship by the gender [15]. In the study conducted by Bayraktar and Yllmaz (2010) which measured the Relationship between Individual Success and Assertiveness Levels of Wrestlers, it was found that female wrestlers are more assertive than males in the Gender variable [16]. When it was examined in general terms, it is possible to say that female participants or athletes are more effective in communication than males and their communication with coaches are stronger.

When the findings of the age variable, of the demographical variables, were examined, it was determined that sub-dimensions of coach-athlete relationship scale (complementing each other, mutual communication and intimacy) did not vary significantly by the age variable (Table 2). That is, we can say that participants at different ages are not effective in determination of the relationship between coach and athletes.

When the related literature was examined, it was seen that there are similar results with research results. Of these, Yücel (2010) found in his study conducted on the wrestlers that there were no significant differences in sub-dimensions of coach-athlete relationship scale of the participants by the age variable [15]. Accordingly, our study's findings and results show similarity. When the findings were examined by the sports branch in which the participant athletes engage, it was concluded that sub-dimensions of coach-athlete relationship scale of the participants (complementing each other, mutual communication and intimacy) did not vary significantly (Table 3). That is, it was seen that the sports branch is not a clear factor in the coach-athlete relationship.

When the results of the school where the athlete studies, of the demographical variables, were examined, it was determined that there were no significant differences in complementing each other and mutual communication sub-dimensions of the sub-dimensions of the coach-athlete relationship scale by the school type; there were differences at significant level in the Intimacy sub-dimension (Table 4). Of these differences, rank means of the athletes who studied at secondary school became evident compared with others. That is, it is possible to say that athletes who study at secondary school are in closer relationships with coaches than the athletes who study at high school, they establish better relationships in their relations than the athletes who study at other schools.

When the related literature was examined, Yücel (2010) concluded in his study related with wrestlers that there were no differences in coach-athlete relationships of the participants by the education status and he presented results that are not parallel with our study.

\section{REFERENCES}

[1] Çalışkan G. Liderlik Açısından Antrenör Davranışlarının Sporcu Performansı Üzerine Etkisinin Değerlendirilmesi. Yüksek Lisans. Kütahya: Dumlupınar Üniversitesi.2001.

[2] Özkal N, Kılıç A.G, Yıldız V. Öğrenci Adlarının Öğretmen Beklentisi ve Öğrencilerin Akademik Başarıları Üzerindeki Etkileri. Eğitim Araştırmaları Dergisi. 1(7).2002.

[3] Robbins, P. S., Decenzo, A. D., \& Coulter, M. Yönetimin esasları. (A. Öğ̈̈, Çev.). Ankara: Nobel Yayın. Dağıtım. 2013.

[4] Koç, S. İletişimde Ustalaşmak (10.bask1), Kuraldış1 Yayınc1lik, 2014, İstanbul, s.27.

[5] Nihat Çalışkan, Mustafa Aslanderen, Aile İçi İletişim ve Siber Yaşam: Teorik Bir Çözümleme, Ahi Evran Üniversitesi Kırşehir Eğitim Fakültesi Dergisi, Cilt 15, Say1 2, Ağustos 2014, s.263-277.

[6] Sunay, H., Saracaloğlu, A. S. "Türk Sporcusunun Spordan Beklentileri ile Spora Yönelten Unsurlar”, Spormetre Beden Eğitimi ve Spor Bilimleri Dergisi, Cilt;I, Say1;1,s.43-48.2003.

[7] Alper Y. Voleybolda Antrenör-Sporcu İlişkisi ve Voleybolcuların Müsabaka Öncesi Kaygı Düzeyleri. Yüksek Lisans Tezi. Sakarya: Sakarya Üniversitesi.1998.

[8] Altıntaş, A., Çetinkalp Z. ve Aşçı H. Antrenör- Sporcu İlişkisinin Değerlendirilmesi: Geçerlik ve Güvenirlik Çalışması. Spor Bilimleri Dergisi, 23(3), 119-128. 2012.

[9] Morgan C.T. Psikolojiye Giriş. H Arıcı(Çeviren). Ankara: Metelgan Yayınları 13. Baskı.1999.

[10] Erdoğan N., Zekioğlu A., Dorak F. Hentbol Antrenörlerine Göre, Sporcuların Performansını Psikolojik Yönden Etkileyen Faktörler Nelerdir? Nitel Çalışma. International Journal of Science Culture and Sport. ISSN: 2148-1148 Doi: 
10.14486/IJSCS89. 2014.

[11] Karasar, N. Bilimsel Araştırma Yöntemi. (31. bask1). Ankara: Nobel Yayın Dağıtım. 2016.

[12] Çilenti, M. Eğitim teknolojisi ve öğretim. Ankara: Kadığlu Matbaas1.1984.

[13] Jowett, S, Ntoumanis, N. The Coach-Athlete Relationship Questionmaire (CART-Q): Development and initial Validation. Scandinavion Journal of Medicine-Science in Sports; 2004.
[14] Ekenci, MT., Yücel, MG., Ekenci, G. Antrenör- Sporcu İlişkisi Ölçeğinin Türkiye İçin Geçerlilik ve Güvenilirlik Analizi. Akademik Sosyal Araştırmalar Dergisi, Y11: 5, Sayı: 40, s. 1-13. 2017.

[15] Yücel, M. Antrenör-Sporcu İlişkisini Etkileyen Faktörler (Güreş Örneği). Yüksek Lisans Tezi. Gazi Üniversitesi Sağlık Bilimler Enstitüsü. Ankara.2010

[16] Bayraktar G., Yılmaz E. Güreşçilerin Bireysel Başarıları ile Atılganlık Düzeylerinin İlişkisi. Konya: Selçuk Üniversitesi Beden Eğitimi ve Spor Bilim Dergisi. 1 (12). 2010. 